\title{
Air Pollution Regulations in China: A Policy Simulation Approach with Evolutionary Game
}

\section{Przepisy dotyczące zanieczyszczenia powietrza w Chinach: podejście do symulacji polityki i gry ewolucyjnej}

\author{
Zhaopeng Chu*, Chen Bian ${ }^{\star \star}$, Jun Yang ${ }^{\star \star \star}$ \\ *School of Humanities and Law, Northeastern University, 195 Chuangxin Road, \\ Hunnan District, Shenyang 110819, China \\ E-mail: kingzhaopeng@gmail.com,ORCID:0000-0002-9284-1602 \\ **School of Business Administration, Northeastern University, Shenyang 110819, China \\ ***F.C. Manning School of Business Administration, Acadia University, Wolfville, \\ NS, B4P 2R6, Canada \\ E-mail (Corresponding Author): jun.yang@acadiau.ca, ORCID: 0000-0002-5796-7672
}

\begin{abstract}
In the institutional context of China's political centralization and fiscal decentralization, this study explores the environmental regulations that make the central and local governments join efforts in air pollution control. Policy simulations in an evolutionary game show that the best approach is to internalize environmental costs and benefits in local governments' objective function. The effectiveness of several policy instruments is examined individually and jointly, including administrative inspection, transfer payment, and environmental taxes. It is shown that in case environmental consequences are not internalized, appropriate application of policy instruments can incentivize goal-oriented local governments to choose the socially optimal strategy.
\end{abstract}

Key words: air pollution, environmental regulation, evolutionary game, numerical simulation

\section{Streszczenie}

W kontekście instytucjonalnym chińskiej centralizacji politycznej i decentralizacji fiskalnej, niniejsze badanie analizuje regulacje środowiskowe, które zmuszają rządy centralne i lokalne do wspólnych wysiłków na rzecz kontroli zanieczyszczenia powietrza. Symulacje polityki w grze ewolucyjnej pokazują, że najlepszym podejściem jest internalizacja kosztów i korzyści środowiskowych w funkcji celu samorządu. Skuteczność kilku instrumentów polityki jest badana indywidualnie i wspólnie, w tym kontroli administracyjnej, płatności transferowych i podatków ekologicznych. Wykazano, że w przypadku braku internalizacji konsekwencji środowiskowych, odpowiednie zastosowanie instrumentów polityki może zmotywować zorientowane na cel samorządy lokalne do wyboru społecznie optymalnej strategii.

Słowa kluczowe: zanieczyszczenie powietrza, degradacja środowiska, gra ewolucyjna, symulacja numeryczna

\section{Introduction}

Despite China's endeavors to promote the Sustainable Development Goals (SDGs) since 2015, its environmental pollution has increasingly drawn public and governmental concerns in the world (Xue et al., 2018). Particularly, the air pollution in the Beijing-
Tianjin-Hebei (BTH) region has occupied media and public discussions in recent years (Ravetti et al., 2019). Several cities in BTH and surrounding areas are among the top ten cities with the worst air quality in the nation, which deviates from the good health and well-being of SDGs. Ironically, governments at all levels in China can orchestrate temporary politi- 
cal blue sky during major international events such as the Beijing Olympic games, which is often followed by a dramatic deterioration in air quality worse than before (Shen and Ahlers, 2019).

Ample attention has been paid to the technical solutions to preventing and controlling air pollution such as flue gas desulfurization and denitration (Yao et al., 2019) and clean coal and low carbon energy technologies (Feldman and Hart, 2018). However, fighting air pollution is far from a technical challenge alone because it requires governments' collaborative will to put technologies to work. Simply put, China's air pollution control hinges on coordination of governments' environmental regulations and implementations.

Effectively fighting air pollution in China requests sound appreciation of its institutional context. Fiscal decentralization and political centralization in China, or Chinese-style decentralization, have promoted astronomical economic growth, but too often local governments prioritize economic development at the expense of environmental pollution (Diao et al., 2009). On the one hand, the Chinese government system is politically centralized with strong topdown mandates, and officials are incentivized by political promotion granted by the central government (Mok and $\mathrm{Wu}, 2013$ ). On the other hand, local governments are given discretionary authority and residual tax rights as a result of fiscal decentralization. Therefore, political centralization determines that China's environmental governance is not environmental federalism but authoritarian environmentalism (Zhao and Percival, 2017). In recent years the central government in China has resolved to lead the way to an ecological civilization, but fiscal decentralization and political promotion present mixed incentives to local government officials (Chen et al., 2016).

Chinese-style decentralization institution makes the evolutionary game theory (EGT) a suited tool for studying the strategic interactions between the central and local governments in fighting air pollution. Initially proposed by Maynard-Smith and Price (1973), EGT provides a promising framework to inquire into changes in beliefs and norms over time and predict the results of competing strategies in a dynamic social setting (Newton, 2018). This study contributes to environmental economics literature by exploring the effects of governmental policies within an EGT framework. This is among the first attempts on conducting environmental policy simulations in EGT. Most applications of EGT in environmental studies have focused on theoretical conditions that would yield the evolutionarily stable strategy (ESS) (Zhao et al., 2018; Jiang et al., 2019; Zhang et al., 2019). Numerical simulations that complement the ESS conditions are almost always parameter sensitivity analysis, mostly regarding the commitment level of parties in the game (Gao et al., 2019; Jiang et al., 2019). Since commitment levels are the out- come of their employed games, these simulations serve to demonstrate the robustness of theoretical results. Sometimes, sensitivity analysis is conducted with respect to a policy-related parameter, such as governmental subsidy in Zhao et al. (2018), ecological compensation fee in Gao et al. (2019), and punishment in Peng et al. (2019). But such an analysis is always of limited scope. In contrast, this study conducts policy simulations involving multiple policy instruments allowed to vary in a broad space, both individually and, more importantly, jointly. We systematically study the effectiveness of three popular policy instruments at the disposal of the central government - environmental supervision, transfer payment, and environmental taxes - in order to uncover their combinations that would lead to the ideal cooperative outcome. This paper thus represents an innovative application of EGT that expands the research toolbox for policy studies on environmental dimensions and beyond.

In order to substantially reduce air pollution reflected in SDGs, we simulate the dynamic interactions between the central and local governments in a wide range of scenarios. The EGT simulations reveal that the best mechanism for fighting air pollution is one in which local governments explicitly consider environmental benefits and losses when formulating their environmental policy. Local governments would have strong incentives to ramp up implementation when environmental performance really affects their interest. Such an endogenous institutional design does not require deliberate intervention by the central government and would intrinsically gain cooperation from local governments. When local governments do not endogenize the environmental consequences in decision-making, however, the central government can design and execute policies with appropriate combinations of policy instruments that would guide local governments towards the ideal collective efforts in air pollution control. Typically, a modest level of environmental inspection is mandatory in effective policy solutions, and the central government should increase the amount of transfer payment to subsidize governance cost by local governments. Environmental tax revenue should be dedicated to environmental protection initiatives to alleviate the common pool problem.

\section{Literature Review}

This study is related to several groups of literature. The literature on environmental regulations in China is massive, many of which recognize its unique social and institutional characteristics. However, little attention has been paid to expressly investigate the effectiveness of authoritarian environmentalism under Chinese-style decentralization. Examining environmental protection from the perspective of fiscal decentralization alone has yielded mixed results (Song et al., 2018), because in China political cen- 
tralization dictates fiscal decentralization. One feature that separates this paper from the literature is its integration of political centralization and fiscal decentralization into a unified framework. Political blue sky is a key environmental issue in China, but most literature is limited to revealing its causes (Shen and Ahlers, 2019), and evaluating its consequences (Liu, et al., 2017). Instead, this study aims to propose solutions to the challenge of political blue sky by modelling and simulating with EGT.

Another group of related literature is those applying EGT in environmental studies. For example, Zhao et al. (2018) analyze the strategic interaction between enterprises and consumers with bounded rationality in a carbon-labeled product market. Peng et al. (2019) build an EGT model involving government regulatory departments and electronics manufacturing enterprises for the implementation of extended producer responsibility for e-waste. Zhang et al. (2019) conduct an evolutionary game model to analyze haze pollution control between a superior government and two local governments from the regional synergistic governance perspective. In contrast, this paper focuses on policy design to promote cooperation between the central and local governments in air pollution control.

More broadly, at an international level, this study complements and extends the literature on environmental federalism (Alm and Banzhaf, 2012). Sjöberg and $\mathrm{Xu}$ (2018) find no evidence of a race-to-the-bottom in the U.S. when states assume more decentralized enforcement responsibilities in environmental protections. Sjöberg (2016)'s study on Swedish municipalities reveal that local politicians affect not only environmental policies, but also the outcome through implementation and enforcement. In an empirical study on 110 countries, Fredriksson and Wollscheid (2014) uncover that environmental policy decentralization tends to be associated with weaker environmental policies, yet this effect is less negative in politically centralized systems. This study explores environmental protection interactions in China, a country featuring strong political centralization yet financial and environmental decentralization. However, the presence of these two features is by no means unique to China, only differing in degree across nations. Decentralized policymaking is shown to yield inefficiently weak policies due to associated neglect of transboundary pollution spillovers (Silva and Caplan, 1997) and inter-jurisdictional capital competition (Kunce and Shogren, 2007). It is also documented that greater political centralization leads local politicians and congressional legislators to pay more attention to national party mandate because their political careers depend on it (Enikolopov and Zhuravskaya, 2007). The results in this study suggest that political centralization can improve environmental policy stringency and collaboration between the central and local governments.

\section{Institutional Context and Policy Instruments}

This section first discusses how Chinese-style decentralization affects governments' environmental regulations in air pollution control. Then, we outline three policy instruments at the disposal of the central government that can guide local governments' strategies to lead to the ideal cooperative outcome. The complex relationship between the central and local governments is depicted in Figure 1.

\subsection{Institutional context}

In response to growing public concerns over the environmental dimensions of SDGs in China, a series of strict environmental regulations have come into effect in recent years. The institutional relationship between the central and local governments is crucial for the implementation of environmental regulations. As shown in Figure 1, China's fiscal system is largely decentralized, while its political structure is centralized with strong top-down mandates and a homogeneous political structure. There are several key issues in understanding the relationship between the central and local governments in environmental protection.

First, in Chinese-style decentralization, the interest between the central and local governments in environmental protection is not completely consistent. For instance, the central government has promulgated the policy of eliminating backward production capacity in high-energy-consuming industries. However, local governments may rely on these to-beeliminated industries for local fiscal revenue and economic growth. Especially in regions with ample energy-intensive industries, there are often local policies and measures to counter the implementation of the central government's policy.

Second, environmental regulation is subject to discretion in implementations, because environmental decentralization requires self-financing by local governments. There exists a clear mismatch between positive externality created by air pollution control and the governance cost borne by local governments (Zhang, et al., 2018). In a goal-oriented environment, local governments greatly value accomplishment measures of GDP growth, which results in intense competition among rival jurisdictions (You et al., 2019). Environmental regulations are an important policy tool for local governments to attract mobile taxpayers by creating lax jurisdictional environmental regulations that lower costs and tax burden borne by firms (Lai, 2019).

Third, despite its determination to fight air pollution, the central government cannot monitor the behaviors or efforts of local governments effectively all the time. The cost of such supervision is prohibitively too high, and the efforts and ambitions of local governments are often unobservable. Therefore, there is information asymmetry within the principal-agent framework of decentralized environmental govern- 


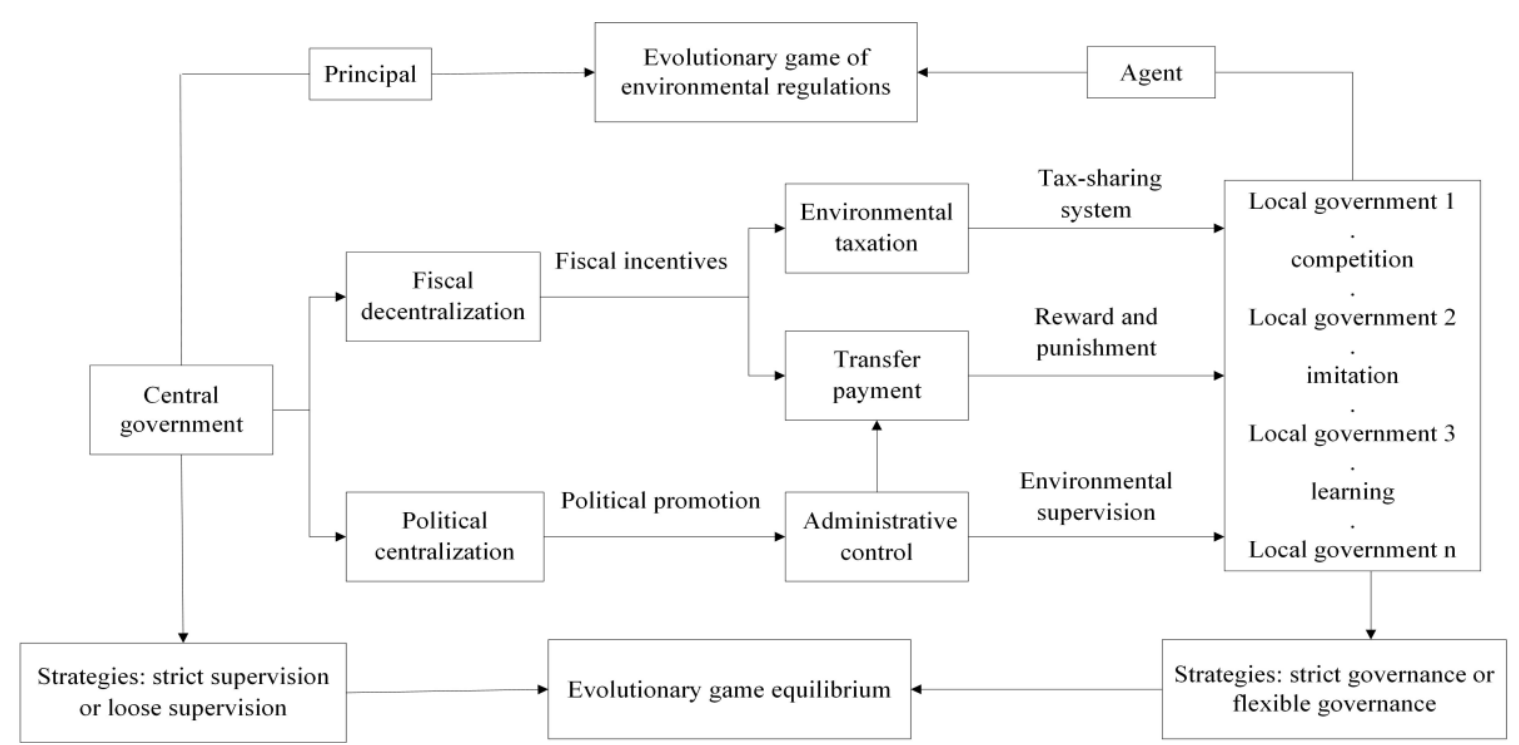

Figure 1. Institutional relationship between central and local governments in air pollution control

ance (Diebecker and Sommer, 2017). The fundamental issue is thus how the central government can design effective institutions with available policy instruments so that local governments are willing to cooperate with it by adopting strict environmental governance.

\subsection{Policy instruments for fighting air pollution}

For the purpose of spurring local environmental governance reform, this section analyzes the conventional and economic policy instruments at the disposal of the central government: administrative inspection, transfer payment, and environmental taxes. The first policy tool is the administrative measure of inspection. A challenge in environmental protection, including air pollution control, is that local environmental protection agencies report to local governments. This relationship entails inevitable conflict of interest. To address this challenge, in 2017 the six regional environmental protection inspection centers of the Ministry of Environmental Protection were officially upgraded to the Regional Environmental Protection Supervision Bureaus and were granted greater power and mandate in environmental inspections. These regional environmental protection agencies report directly to the central government and are responsible for carrying out a larger share of monitoring, supervision, and enforcement of environmental regulations. The central government can choose strict supervision strategy (enforcing all-round environmental protection supervision) or loose supervision strategy (carrying out spot checks in selected areas) via national and regional environmental supervision authorities. However, in Chinese-style decentralization, local governments have enough autonomy to choose a strict or lax governance strategy. Environmental inspection is thus a key policy tool for the central government to push and motivate local governments to carry out strict governance.
Because their economy features heavy polluting industries, some regions such as the BTH face overwhelming challenges in fighting air pollution. These heavily polluted provinces are in urgent need for subsidies from the central government and tax revenues in their fight against pollution (Chu et al., 2018). In order to implement the Air Pollution Prevention and Control Action Plan, in 2013 the central government established a dedicated fund for air pollution control with an initial annual budget of 5 billion yuan. The fund significantly increased year by year to 16 billion yuan in 2017. As local governments often undertook unauthorized use and lax management of this dedicated fund, a new institutional system needs to be designed to hold local governments accountable. This system would be a combination of the vertical transfer payment in fiscal decentralization and the reward and punishment in political centralization, to regulate local governments' opportunistic free-riding behaviors. Once local governments are found for not strictly controlling air pollution, they would be subject to punishment by the central government: a complete refund of the allocated special funds, plus an administrative fine of the equal amount.

Environmental taxation has replaced the pollutant discharge fee to get China's air pollution under control since January 2018. However, local governments have conflicting incentives for collecting environmental protection taxes. On one hand, facing the challenges of economic transformation and tight fiscal budget, local governments may tend to collect environmental taxes at higher rates on more pollutants when they strictly control air pollution. On the other hand, the Laffer Curve suggests that maintaining a moderate overall tax burden is an important condition for promoting economic growth (Aslim and Neyapti, 2017). Nowadays, the tax burden on Chinese enterprises is substantial despite govern- 
ments' attempt to reduce it. The environmental protection taxes have increased the overall rate of the tax system, resulting in an increase in business operating costs and a possible reduction in tax base. Therefore, it is possible that environmental tax revenues may decline when local governments strictly tax polluting firms at higher rates. In extreme cases, polluting enterprises might be forced to shut down, thus paying no taxes to the local government. It is common for polluting enterprises to shop around for jurisdictions with a lower tax burden and local governments often work hard to attract these mobile taxpayers and job creators. Given the central government's vertical transfer payment, the low-tax-burden competition among local governments creates a common pool problem in air pollution control in which they want to pass on more costs to the central government (Saarimaa and Tukiainen, 2015). In this study we would consider the two policy parameters to investigate regarding the environmental taxes: the tax burden (low vs. high) and the retaining ratio by local governments and examine how they may impact the evolutionary game equilibrium.

\section{The Evolutionary Game Model}

\subsection{The game setup}

Based on arguments above, the interaction between the central and local governments in air pollution control can be modelled as a non-cooperative evolutionary game as follows.

Variables $C_{1}$ and $C_{2}$ represent the costs of strict and lax governance respectively in air pollution control to local governments, which include the implementation cost of environmental regulation. It is assumed $C_{1}>C_{2}$, as strict enforcement carries a higher cost. The collected environmental protection taxes are shared by the local and central governments, with $0 \leq \alpha \leq 1$ representing the share for local governments. $R_{1}$ and $R_{2}$ represent total environmental tax revenues when local governments adopt strict and lax governance respectively in air pollution control. Intuitively it is assumed that $R_{1}>R_{2}$, but if the tax burden is so high that some enterprises have to reduce production or are forced to shut down, then $R_{1}<R_{2}$. Such a relationship between tax rates and tax revenues is known as the Laffer Curve in economics.

The net benefit created by local governments adopting strict governance in air pollution control is $\Delta_{l}$ and the loss caused by lax governance is $\Delta_{2}$. Given the dreadful smog situation in China, it is assumed that $\Delta_{1}<\Delta_{2}$. That is, strict governance will improve the situation, but doing little or nothing would make

${ }^{1}$ From the modelling perspective, the central government including various relevant ministries and administrative arms such as the regional supervision bureaus is treated as a single entity, and local governments are treated as a ho- it much worse. The spillover coefficient for net benefit or loss is denoted by $0<\eta<1$, indicating net benefit or loss regarding air pollution control in the jurisdiction of a local government would spill over to adjacent regions, which is considered part of the benefit or loss to the central government that oversees the whole nation.

The supervision cost of the central government is $C_{3}$. $J$ is the transfer fund to a local government for air pollution control; if a local government is caught for incompliantly spending the fund, it will be subject to an administrative fine of the same amount. In order to quantify the intensity of the central government's environmental supervision, $\beta$ represents the probability of the central government to inspect a particular jurisdiction. When the central government chooses the strict supervision strategy, $\beta=1$.

To sum up, Table 1 shows the payoff matrix for the central and local governments.

Table 1. Payoff matrix for the central and local governments

\begin{tabular}{|c|l|l|}
\hline \multirow{2}{*}{$\begin{array}{c}\text { Local } \\
\text { governments }\end{array}$} & \multicolumn{2}{|c|}{ Central government } \\
\cline { 2 - 3 } & Strict supervision & \multicolumn{1}{c|}{ Loose supervision } \\
\hline Strict & $-C_{1}+\alpha R_{1}+\Delta_{1}+J$ & $-C_{1}+\alpha R_{1}+\Delta_{1}+J$ \\
governance & $-C_{3}+(1-\alpha) R_{1}+\eta \Delta_{1}-J$ & $-\beta C_{3}+(1-\alpha) R_{1}+\eta \Delta_{1}-J$ \\
\hline Lax & $-C_{2}+\alpha R_{2}+\Delta_{2}-J$ & $-C_{2}+\alpha R_{2}-\Delta_{2}+(1-2 \beta) J$ \\
governance & $-C_{3}+(1-\alpha) R_{2}+\eta \Delta_{2}+J$ & $-\beta C_{3}+(1-\alpha) R_{2}-\eta \Delta_{2}-(1-2 \beta) J$ \\
\hline
\end{tabular}

\subsection{Evolutionary analysis of the game}

Assume the local government adopts strict governance with probability $x$ and lax governance with probability $1-x$. In the meantime, the central government chooses strict supervision with probability $y$, and loose supervision with probability $1-y .{ }^{1}$

The expected utility of a local government adopting strict governance is

$U_{1}=y\left(-C_{l}+\alpha R_{1}+\Delta_{1}+J\right)+(1-y)$

$\left(-C_{l}+\alpha R_{l}+\Delta_{l}+J\right)$

and its expected utility of adopting lax governance is $U_{2}=y\left(-C_{2}+\alpha R_{2}-\Delta_{2}-J\right)+(1-y)\left[-C_{2}+\alpha R_{2}-\right.$

$\left.\Delta_{2}+(1-2 \beta) J\right]$.

The overall expected utility of a local government is $\overline{U_{12}}=x U_{1}+(1-x) U_{2}$.

Similarly, the expected utility of the central government choosing strict supervision is

$U_{3}=x\left[-C_{3}+(1-\alpha) R_{1}+\eta \Delta_{1}-J\right]+(1-x)\left[-C_{3}+\right.$

$\left.(1-\alpha) R_{2}-\eta \Delta_{2}+J\right]$

and its expected utility of choosing loose supervision is

$U_{4}=x\left[-\beta C_{3}+(1-\alpha) R_{1}+\eta \Delta_{1}-J\right]+$

$(1-x)\left[-\beta C_{3}+(1-\alpha) R_{2}-\eta \Delta_{2}-(1-2 \beta) J\right]$.

The overall expected utility of the central government is

mogenous group. In practice, as there is a multitude of local governments, $x$ can be understood as the percentage of them adopting strict governance. Due to the uniqueness of the central government, $y$ is best understood as the probability for its adoption of strict supervision. 
$\overline{U_{34}}=y U_{3}+(1-y) U_{4}$.

The replicator dynamics equation of the game system is:

$$
\left\{\begin{array}{c}
\frac{d x}{d t}=x(1-x)\left[C_{2}-C_{1}+\Delta_{1}+\Delta_{2}+\alpha\left(R_{1}-R_{2}\right)+\right. \\
2 \beta J+2 y J(1-\beta)] \\
\frac{d y}{d t}=y(1-y)\left[(1-\beta)\left(2 J-C_{3}\right)-2 x J(1-\beta)\right]
\end{array}\right.
$$

For the replication dynamic system (7), there are 4 sets of potential pure-strategy Nash equilibria, i.e., $(0,0),(0,1),(1,0)$, and $(1,1)$ that are fixed points of the evolutionary dynamics, which can be determined by the Jacobian matrix partial stability (Friedman, 1991).

In the determinant and trace of the Jacobian matrix, it can be expressed that $\pi_{1}=C_{2}-C_{1}+\Delta_{1}+\Delta_{2}+\alpha$ $\left(R_{1}-R_{2}\right)+2 \beta J$ represents the net benefit to local governments adopting strict governance when the central government employs loose supervision, and $\pi_{2}=C_{2}-C_{1}+\Delta_{1}+\Delta_{2}+\alpha\left(R_{1}-R_{2}\right)+2 J$ represents the net benefit to local governments adopting strict governance when the central government employs strict supervision. Similarly, $\pi_{3}=(\beta-1) C_{3}$ represents the net benefit to the central government employing strict supervision when local governments adopt strict governance, and $\pi_{4}=(1-\beta)\left(2 J-C_{3}\right)$ represents net benefit to the central government employing strict supervision when local governments adopt lax governance. When $0<\beta<1$, we have $\pi_{1}<\pi_{2}, \pi_{3}<\pi_{4}$, and $\pi_{3}<0$. Therefore, the evolutionary stability of equilibrium points is summarized in Table 2 that includes six situations.

There is no ESS between the central and local governments in the $6^{\text {th }}$ situation, as all the game outcomes are saddle points thus unstable. However, there may exist mixed-strategy equilibrium in which participants would evolve and interact with each other strategically over time.

In the other five situations presented in Table 2, there exists an ESS point to which the evolutionary game system will coverage in equilibrium. Among the four pure-strategy outcomes, $(0,1)$ corresponds to the worst evolutionary equilibrium of non-cooperation when local governments adopt lax governance while the central government chooses strict supervision. On the contrary, point $(1,0)$ corresponds to the optimal and thus ideal evolutionary equilibrium of cooperation when local governments adopt strict governance under loose supervision from the central government. It is deemed optimal due to the low aggregate governance cost for accomplishing the desired outcome. Besides, constant high pressure from the central government would not be a sustainable solution. Instead, the central government should focus on guiding local governments' choice with well-designed regulations. Points $(0,0)$ and $(1,1)$ are deemed the second worst and suboptimal evolution equilibriums respectively.
From the policy perspective, the principal issue is to design policies so that the point $(1,0)$ is the ESS in the dynamic interactions between the central and local governments. This ESS is ideal because the intensity of environmental supervision enforced by the central government is low due to its trust on local governments to fight air pollution diligently. Thus, in the evolutionary game system, the question is how to incentivize more local governments to adopt strict governance when the central government does not have to keep high-intensity supervision. In the next section, we will investigate via simulations the individual and joint effect of the policy instruments to accomplish this objective.

\section{Simulation Analyses of the Evolutionary Game}

In this section, we first assign the parameters in the dynamic model based on official information and existing literature, and then study their impact in two scenarios via simulations. In practical scenarios, it is assumed that local governments do not directly consider environmental impacts when formulating their policies, while in theoretical scenarios they explicitly incorporate environmental cost and benefit into decision-making. In both scenarios we aim to examine the impact and effectiveness of various policy instruments in leading to ESS.

\subsection{Parameter assignments}

Among the parameters in the evolutionary game model (7), $C_{1}, \Delta_{2}$ and $R_{1}$ are the main parameters, and the others can be set according to their relationship with them. Unfortunately, it is impossible to directly collect their data from any official or other reputable source of information. Based on the principle of uniformity and availability, the national environmental pollution loss measured in Liu and Wen (2008) is assigned for $\Delta_{2}$, the total amount of investment in environmental pollution control obtained from the National Environmental Statistics Bulletin is assigned for $C_{1}$, and the pollutant discharge fee from the same source is assigned for $R_{l}$. The ratio of these three variables is calculated as $C_{1}: \Delta_{2}: R_{1}=1: 0.5: 0.05$. Therefore, in simulations they are assigned as $C_{1}=10, \Delta_{2}=5$ and $R_{1}=0.5$. Besides, $C_{2}=4$ satisfies the assumption that the cost of lax governance is less than that of strict governance, and $\Delta_{l}=2$ satisfies the assumption that the environmental benefit of strict governance is less than the environmental loss due to lax governance. $R_{2}=0.3$ satisfies the assumption that the environmental tax revenue from lax governance is less than that from strict governance, and $C_{3}=0.5$ assigned by the pollutant discharge fee is regarded as the supervision cost of the central government (He, 2015). In simulations, the step for parameters $\beta, \alpha, J$ and $R_{1}$ is 0.1 . The value interval of $\beta$ is $[0.1,0.9]$ with $\beta=0.5$ as the initial state. Respectively, the value interval for $\alpha$ is $[0,1]$ with the initial state of $\alpha=0.5$, 
Table 2. Evolutionary stability of equilibrium points

\begin{tabular}{|c|c|c|c|c|c|c|c|c|c|}
\hline situation & \multicolumn{3}{|c|}{$\# 1$} & \multicolumn{3}{|c|}{$\# 2$} & \multicolumn{3}{|c|}{$\# 3$} \\
\hline \multirow{2}{*}{$(x, y)$} & \multicolumn{3}{|c|}{$\pi_{l}>0, \pi_{4}>0$} & \multicolumn{3}{|c|}{$\pi_{l}>0, \pi_{4}<0$} & \multicolumn{3}{|c|}{$\pi_{l}<0, \pi_{2}<0, \pi_{4}<0$} \\
\hline & det & trI & Stability & det & $t r I$ & Stability & det & $t r I$ & Stability \\
\hline$(0,0)$ & + & + & Unstable & - & & Saddle & + & - & ESS \\
\hline$(0,1)$ & - & & Saddle & + & + & Unstable & - & & Saddle \\
\hline$(1,0)$ & + & - & ESS & + & - & ESS & - & & Saddle \\
\hline$(1,1)$ & - & & Saddle & - & & Saddle & + & + & Unstable \\
\hline situation & & & & \multicolumn{3}{|c|}{$\# 5$} & \multicolumn{3}{|c|}{$\# 6$} \\
\hline \multirow{2}{*}{$(x, y)$} & \multicolumn{3}{|c|}{$\pi_{1}<0, \pi_{2}<0, \pi_{4}>0$} & & $\overline{<0,}$ & $0, \pi_{4}<0$ & & $<0$ & $0, \pi_{4}>0$ \\
\hline & det & $t r I$ & Stability & det & $t r I$ & Stability & det & trI & Stability \\
\hline$(0,0)$ & - & & Saddle & + & - & ESS & - & & Saddle \\
\hline$(0,1)$ & + & - & ESS & + & + & Unstable & - & & Saddle \\
\hline$(1,0)$ & - & & Saddle & - & & Saddle & - & & Saddle \\
\hline$(1,1)$ & + & + & Unstable & - & & Saddle & - & & Saddle \\
\hline
\end{tabular}

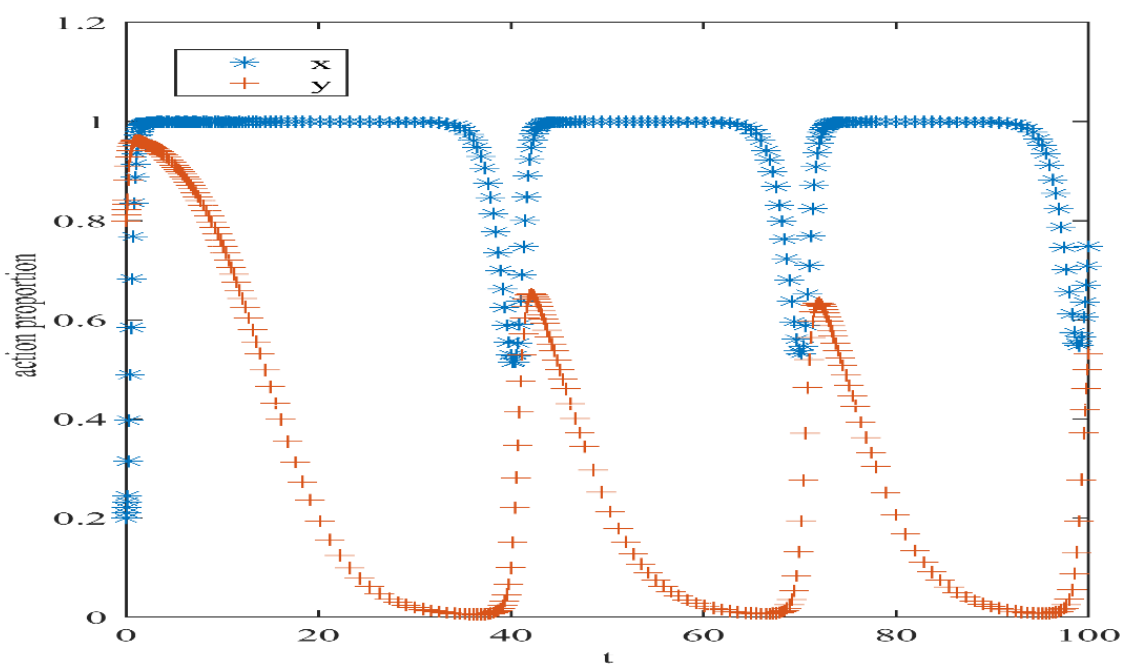

Figure 2. Dynamic evolutionary process in practical scenario. For vertical axis, $x$ and $y$ represent the proportion (probability) of local governments and the central government taking strict governance or supervision, respectively. The horizontal axis $t$ represents the round of simulation.

and the value interval for $J$ is $[0.1,10]$ with the initial state of $J=5$.

\subsection{Simulation of practical situations}

Practically, Local governments value greatly economic indicators such as GDP growth and fiscal revenues, often disregarding environmental benefits and losses when formulating their air pollution control policies. Accordingly, $\Delta_{1}=\Delta_{2}=0$ is assumed in the practical simulations in this section, and other parameters are assigned as per Section 5.1. Our interest is to examine the effect of several policy parameters: the sharing of the environmental tax, the environmental tax burden, the intensity of environmental supervision, and the transfer payment by the central government.

\subsubsection{Convergence of the system}

The simulation begins with $x=0.2$ and $y=0.8 .^{2}$ The dynamic evolutionary process is depicted in Figure
2, showing a mixed strategy features the saddle point $(19 / 20,9 / 50)$, around which the strategic choices of both sides of the game display a cyclical pattern. The central government's position swings between loose and modest-intensity supervision, while local governments are sometimes committed to governance and half-heartedly so at other times.

\subsubsection{Effect of sharing environmental tax revenues}

The evolutionary process is simulated when the value of $\alpha$ is 0 and 1 . When $\alpha=0$ there is one saddle point $(19 / 20,1 / 5)$, and when $\alpha=1$ the saddle point is $(19 / 20,4 / 25)$. Further, the results show that when $\alpha$ varies between 0 and 1 , it is impossible to make net benefits positive for local governments adopting strict governance. Therefore, the way environmental tax revenue is shared between the central and local governments is not a valid policy parameter. As a result, only $\alpha=1$ is considered hereafter given that environmental taxes belong to local taxes in practice. 


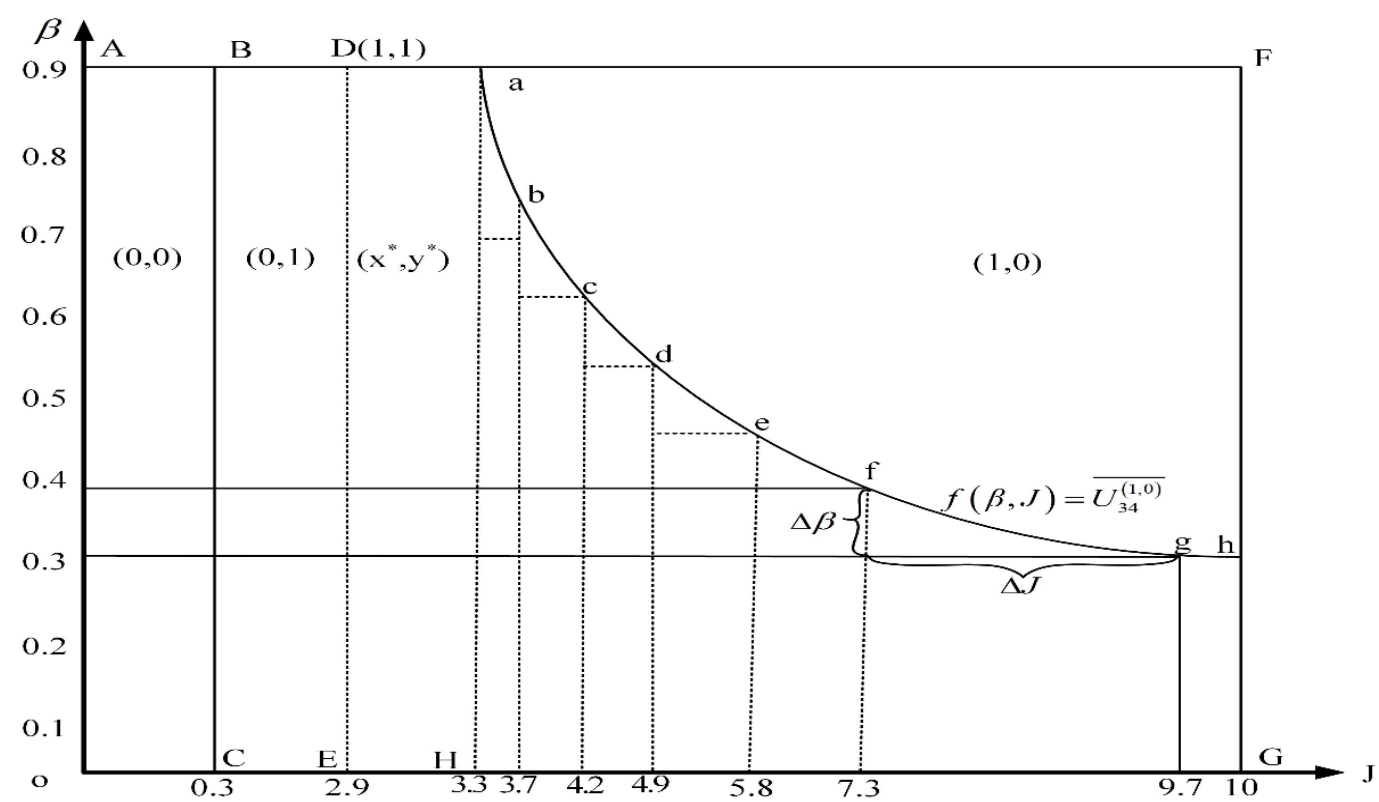

Figure 3. Dynamic evolutionary outcome in practical scenario when $\beta$ and $J$ chang simultaneously

\subsubsection{Effect of the intensity of environmental super- vision}

When only $\beta$ varies, there are saddle points in simulation outcomes when $\beta$ falls in the range of [0.1, $0.6)$, and the system converges to the optimal ESS $(1,0)$ when $\beta$ falls in $[0.6,0.9]$. These simulation results indicate that the central government must maintain at least modest supervision intensity $(\beta \geq 0.6)$ in order to yield the optimal equilibrium.

\subsubsection{Joint effect of environmental supervision and transfer payment}

Now we conduct simulations when parameters $\beta$ and $J$ change simultaneously while keeping the other parameters unchanged and $\alpha=1$. The outcome of the evolutionary game is summarized in Figure 3.

When the central government's supervision intensity $\beta$ is less than 0.3 , no matter how the value of $J$ changes in the interval $[0.1,10]$, the system cannot converge to the optimal ESS $(1,0)$. This means that the precondition for transfer payment with reward and punishment to work, is that the central government must enforce at least three-tenths of the maximum environmental supervision intensity in order to achieve the ideal ESS.

When $J$ falls in the interval $[0.1,0.3)$, represented by the area AOCB in Fig. 3, the system converges to the second worst equilibrium, $(0,0)$. Both the central and local governments adopt a laissez-faire strategy when the level of transfer payment is trivial.

When $J$ increases to the range of $[0.3,2.9)$, the worst equilibrium $(0,1)$ is realized, as denoted by the area of BCED. Local governments always choose lax governance regardless of the amount of transfer payment $J \in[0.3,2.9)$. It is the worst because local governments do not strictly control air pollution while the central government wastes money on supervision costs. The reason for this insensitivity is that the ex- pected cost of air pollution control to local governments is too high relative to the transfer payment offered by the central government. Despite the possible economic and political punishments by the central environment's supervision, many local governments still believe that the law cannot punish all offenders and choose to adopt lax governance. Such a strategy is imitated and becomes the stable strategy in the group.

When $J$ equals 2.9 , the central government's evolutionary stable strategy is strict supervision, and local governments choose strict governance with a probability between 0.1 and 0.2 . The system reaches the suboptimal evolutionary equilibrium $(1,1)$ marked as D.

Only when $J$ is greater than 2.9 does the central government have both the environmental supervision $(\beta)$ and transfer payment $(J)$ effective to incentivize local governments to diligently fight air pollution. The two instruments can be exchanged without affecting the central government's utility. The indifference curve located in upper-right portion of Fig. 3 suggests the law of diminishing marginal rate of substitution between environmental supervision $(\beta)$ and transfer payment $(J)$. The area above the indifference curve represents where the optimal equilibrium (1, 0 ) occurs, and the area below the indifference curve plus the area DEHa represents where the system cannot reach a stable equilibrium.

\subsubsection{Effect of environmental tax burden}

All simulations thus far assume $R_{1}>R_{2}$, that is, adopting strict environmental governance would increase the tax revenues for local governments. However, local governments are often concerned that environmental tax may drive polluting enterprises to other jurisdictions, which makes them suffer in economic growth. Next, we will investigate how this 
Table 3. Effects of environmental tax burden on the optimal evolutionary equilibrium

\begin{tabular}{|c|c|c|c|c|c|c|c|c|}
\hline & $R_{1}$ & \multicolumn{7}{c|}{$\beta$} \\
\hline & & $\beta=0.3$ & $\beta=0.4$ & $\beta=0.5$ & $\beta=0.6$ & $\beta=0.7$ & $\beta=0.8$ & $\beta=0.9$ \\
\hline \multirow{3}{*}{$J$} & $R_{l}=0.5$ & {$[9.7,10]$} & {$[7.3,10]$} & {$[5.8,10]$} & {$[4.9,10]$} & {$[4.2,10]$} & {$[3.7,10]$} & {$[3.3,10]$} \\
\cline { 2 - 9 } & $R_{1}=0.2$ & & {$[7.7,10]$} & {$[6.1,10]$} & {$[5.1,10]$} & {$[4.4,10]$} & {$[3.9,10]$} & {$[3.4,10]$} \\
\cline { 2 - 8 } & $R_{l}=0.1$ & & {$[7.8,10]$} & {$[6.2,10]$} & {$[5.2,10]$} & {$[4.5,10]$} & {$[3.9,10]$} & {$[3.5,10]$} \\
\hline$\left|\Delta J_{0.5}\right|$ & & & 2.4 & 1.5 & 0.9 & 0.7 & 0.5 & 0.4 \\
\hline$\left|\Delta J_{0.2}\right|$ & & & & 1.6 & 1 & 0.7 & 0.5 & 0.5 \\
\hline$\left|\Delta J_{0.1}\right|$ & & & & 1.6 & 1 & 0.7 & 0.6 & 0.4 \\
\hline$\Delta J^{\prime \prime}$ & & & 0.4 & 0.3 & 0.2 & 0.2 & 0.2 & 0.1 \\
\hline$\Delta J^{\prime \prime}$ & & & 0.5 & 0.4 & 0.3 & 0.3 & 0.2 & 0.2 \\
\hline
\end{tabular}

concern $\left(R_{1}<R_{2}\right)$ may affect the evolutionary outcome.

When simulating Sections 5.2.1 and 5.2.2 again with $R_{1}<R_{2}$ and $R_{1} \in[0.1,0.2]$, it is found that there is no evolutionary stable strategy between the central government and local governments.

Compared to Section 5.2.3, the concern for the negative effect of an environmental tax burden by local governments makes the central government slightly elevate its supervision intensity to $\beta \in[0.7,0.9]$, so that the system can reach the optimal ESS.

Compared to Section 5.2.4, the concern for the negative effect of environmental tax burden by local governments raises the values of $\beta$ and $J$ at the optimal ESS point $(1,0)$. Specifically, when $\beta<0.4$, no matter how $J$ changes, the system cannot reach the optimal equilibrium. When $\beta$ varies, the required interval of $J$ for system to reach the second worst equilibrium $(0,0)$ is unchanged from Section 5.2.4. However, the required interval of $J$ for the system to reach the worst equilibrium $(0,1)$ expands slightly to $[0.3,3.1)$. When $J=3.1$, the system converges to the suboptimal equilibrium $(1,1)$. When $J>3.1$, the joint effect of $\beta$ and $J$ complies with the law of diminishing marginal rate of substitution, which is shown in Table 3.

In Table 3, rows 3-5 show the range of $J$ under different combinations of $R_{1}$ and $\beta$ such that the system would converge to the optimal equilibrium. Rows 6-8 show the incremental change in the length of interval of $J$ when $\beta$ increases corresponding to rows 3-5 respectively. The last two rows show the change in the length of the interval for $J$ when $R_{l}$ equals 0.2 or 0.1 (row 4 or 5 ) compared to the case $R_{1}=0.5$ (row 3) within each column. The results show that as $\beta$ increases steadily, the incremental change $|\Delta J|$ for the system to reach the optimal equilibrium is diminishing more slowly (rows 6-8). Meanwhile, compared to the case $R_{1}=0.5$, when $R_{l}$ decreases from 0.2 to 0.1 , the required variation of $\Delta J$ for the system to reach the optimal evolutionary equilibrium is increasing. This relationship between $R_{l}$ and $J$ characterizes the common pool problem in air pollution control - local governments with environmental tax discretion prefer to shift the governance costs through fiscal transfer payments to the central government.
To summarize the simulation results in the practical scenarios, in order to make local governments choose strict governance, the central government can use the administrative measure of environmental inspection $(\beta)$, or combine it with the incentive measure of transfer payments $(J)$. Although sharing environmental tax revenues cannot make local governments undertake strict governance, these revenues would somewhat counter their preference for lax governance. The collection and expenditure of environmental tax revenues are regulated by the central government, which can restrain local governments' discretion of low tax burden competition and alleviate the common pool problem of passing costs to the central government. In short, when the administrative and fiscal tools are coordinated, goal-oriented local governments will participate in the collective action against air pollution.

\subsection{Simulation of theoretical situations}

In the theoretical situations, it is assumed that local governments incorporate the envirmental benefits and losses caused by their environmental policies into decision-making. Based on Section 5.1, $\Delta_{l}=2$ and $\Delta_{2}=5$ are assigned, and the other parameters stay the same as in Section 5.2. Similarly, our interest is to examine the effectiveness of the policy parameters on the ESS.

Figure 4 depicts the evolutionary equilibrium of the game system, in which the strategy of local governments quickly converges to 1 (strict governance) and the strategy of the central government converges to 0 (loose supervision) within 30 rounds of simulation. The regulatory game thus converges to the optimal ESS.

Now we turn to the effects of policy instruments in terms of shaping the evolutionary equilibrium. Corresponding to Sections 5.2.2 to 5.2.5, we sequentially examine the effect of related policy parameters. In all these simulations, no matter how the policy parameters change within their range, the ESS point is always $(1,0)$. Therefore, regardless of the setups for the three policy instruments - environmental tax revenue sharing, environmental inspection, and transfer payment - the game system will always converge to the ideal equilibrium, if the environmental costs and benefits are incorporated in decision-making. 


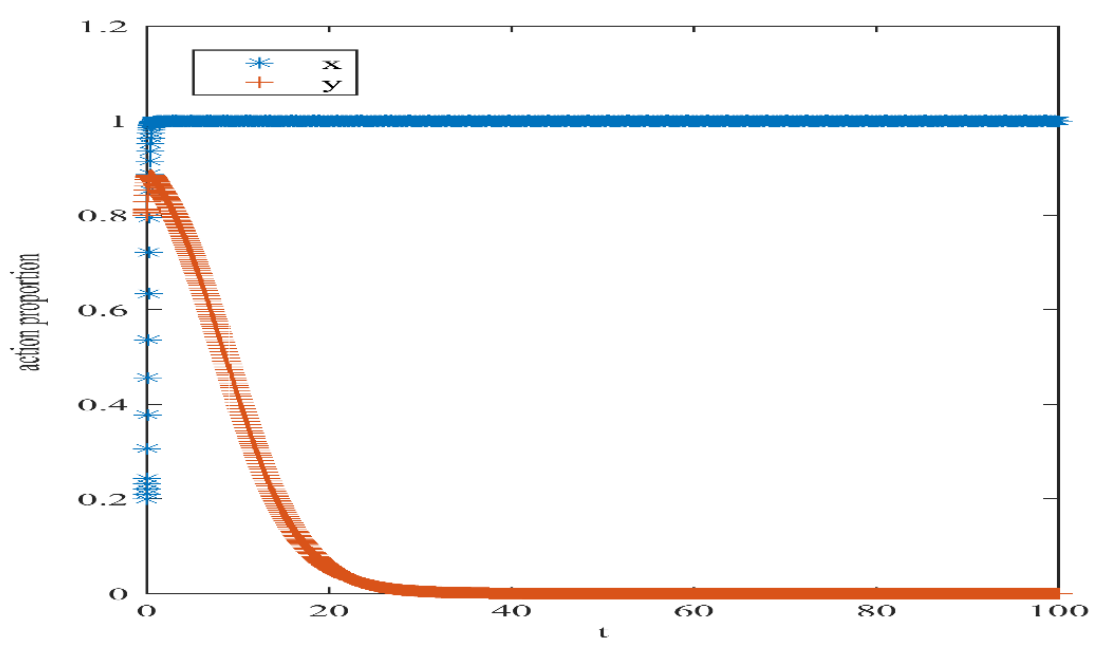

Figure 4. Evolutionary equilibrium in theoretical scenario

The invalidity of these policy instruments brings important enlightenment to China's environmental protection challenges. For the goal-oriented bureaucrats, the endogenization of environmental protection costs and benefits is much more effective than exogenous institutional instruments such as inspection or the carrot and stick effect with transfer payment. When Green GDP is incorporated in the performance evaluation system, local government officials would have to accommodate environmental consequences in their policymaking. Simulations demonstrate that such deliberations would naturally lead to the socially desirable outcome, without any intervention by the central government.

\section{Conclusions}

In China, fiscal and environmental decentralization leads to a race to the bottom among local governments that adopt lax air pollution regulations. This study explores how to bring local governments on board fighting air pollution via policy design. New to literature, policy simulations are conducted in a non-cooperative evolutionary game to explore how to shape cooperative actions.

In the theoretical scenario, when local governments explicitly consider the environmental benefits and losses of air pollution control, the ideal equilibrium will emerge naturally, regardless the central government's policies. When environmental performance is endogenized in local authority performance measures and the promotion standards for the goaloriented bureaucrats, collective actions would naturally emerge among local governments. In the practical scenario, when local governments do not endogenize environmental benefits and losses in decision-making, the central government can design and execute policies with appropriate combinations of environmental inspection and transfer payments to propel local governments to cooperate.
The results in this study offer several important policy implications. First, the most effective institutional design leading to the ideal cooperation in fighting air pollution features indicators on environmental protection explicitly included in statutory local authority performance measures. In practice, one-vote veto system would change the governmental mindset by sending the clear message that no officials would be promoted if they fail in environmental protection.

Second, despite the political will to construct ecological civilization, the central government does not possess enough information to hold local governments accountable for their opportunistic behaviors. For this reason, China's centralization of environmental oversight is necessary to overcome conflict of interest and attain high-quality regulations and monitoring. Reforms such as the establishment of Regional Environmental Protection Supervision Bureaus within the Ministry of Ecology and Environment represents solid progress in this direction. Therefore, good governance of air pollution will be achieved with policies that combine effective highquality institutions with professional officials who are accountable for cultivating ecological civilization.

Third, the central government should transfer more funds for environmental protection to fill local financial capacity gaps. Local governments have borne a disproportionally large share of the costs for environmental protection. For example, in 2015, the nationwide total investment in pollution control was 880.63 billion yuan, and the direct investment in pollution control facilities was 469.42 billion yuan. However, in 2017, the central government allocated only 49.7 billion yuan dedicated to environmental protection. As demonstrated in simulation results, insufficient transfer payments would not be able to spark effective environmental protection by local governments. 
Fourth, measures must be adopted to address the controversial common pool problem in the financial transfer system. Local governments are responsible for collecting environmental taxes and are given a certain level of discretion to spend them. Since local governments usually prefer to keep a relatively low tax burden in order to attract investments, they tend to collect insufficient environmental taxes on polluting firms, which tightens their budgets and thereby reduces investment in environmental protection. Such behaviors by local governments increase their reliance on the financial transfer from the central government. To control rent-seeking of local governments, the environmental tax revenues should be put in special funds strictly dedicated to environmental protection. In the meantime, the central government needs to enhance tax and environmental authorities' capacity to better direct financial resources to environmental protection so that local governments cannot shift the costs of pollution control to central transfer payments.

A few ideas generated in this study warrant exploration in future research. For example, as an additional policy measure, how would inter-regional horizontal transfer payments may affect evolutionary game equilibrium? In addition, air quality has been temporarily improved worldwide due to the Covid-19 pandemic and lockdowns in most countries since the spring of 2020. It is of great interest to explore how a similar but lasting effect can be achieved with sound environmental governance. These ideas will be pursued in upcoming projects.

\section{Acknowledgement}

This work is supported by the National Social Science Foundation of China [grant number 17BJY054] and National Natural Science Foundation of China [grant numbers 71971048 and 71973056$]$.

\section{References}

1. ALM J., BANZHAF H. S., 2012, Designing economic instruments for the environment in a decentralized fiscal system, Journal of Economic Surveys, 26(2): 177-202.

2. ASLIM E. G., NEVAPTI B., 2017, Optimal fiscal decentralization: Redistribution and welfare implications, Economic Modelling, 61: 224-234.

3. CHEN X. D., QIN Q. D., WEI Y. M., 2016, Energy productivity and Chinese local officials' promotions: Evidence from provincial governors, Energy Policy, 95: 103-112.

4. CHU Z. P., LIU C. X., LI G., GUAN K. X., 2018, Sustainable development of the economic circle around Beijing: A view of regional economic disparity, Sustainability, 10: 3691.

5. DIAO X. D., ZENG S. X., TAM C. M., TAM V. W., 2009, EKC analysis for studying economic growth and environmental quality: A case study in China, Journal of Cleaner Production: 17(5): 541-548.

6. DIEBECKER J., SOMMER F., 2017, The impact of corporate sustainability performance on information asymmetry: The role of institutional differences, in:
Review of Managerial Science: 11(2): 471-517.

7. ENIKOLOPOV R., ZHURAVSKAYA E., 2007, Decentralization and political institutions, Journal of Public Economics, 91: 2261-2290.

8. FELDMAN L., SOL HART P., 2018, Climate change as a polarizing cue: Framing effects on public support for low-carbon energy policies, Global Environmental Change, 51: 54-66.

9. FREDRIKSSON P. G., WOLLSCHEID J. R., 2014, Environmental decentralization and political centralization, Ecological Economics, 107: 402-410.

10. FRIEDMAN D., 1991, Evolutionary game in economics, Econometrica, 59(3): 637-666.

11. GAO X., SHEN J. Q., HE W. J., SUN F. H., ZHANG Z. F., GUO W. J., ZHANG X., KONG Y., 2019, An evolutionary game analysis of governments' decision-making behaviors and factors influencing watershed ecological compensation in China, Journal of Environmental Management, 251: 109592.

12. HE Q. C., 2015, Fiscal decentralization and environmental pollution: Evidence from Chinese panel data, in: China Economic Review, 36: 86-100.

13. JIANG K., YOU D. M., MERRILL R., LI Z. D., 2019, Implementation of a multi-agent environmental regulation strategy under Chinese fiscal decentralization: An evolutionary game theoretical approach, Journal of Cleaner Production, 214: 902915.

14. KUNCE M., SHOGREN J. F., 2007, Destructive interjurisdictional competition: Firm, capital and labor mobility in a model of direct emission control, Ecological Economics, 60(3): 543-549.

15. LAI Y. B., 2019, Environmental policy competition and heterogeneous capital endowments, Regional Science and Urban Economics, 75: 107-119.

16. LIU H. L., HE J., GUO J. P., MIAO Y. C., YIN J. F., WANG Y., XU H., LIU H., YAN Y., LI Y., ZHAI P. M., 2017, The blue skies in Beijing during APEC 2014: A quantitative assessment of emission control efficiency and meteorological influence, Atmospheric Environment, 167: 235-244.

17. LIU Y. L., WEN H. D., 2008, The trend and forecast of environment loss based on economic analyze, Ecological Environment, 1: 376-380 (in Chinese).

18. MAYNARD-SMITH J., PRICE G. R., 1973, The logic of animal conflict, Nature, 246: 15-18.

19. MOK K. H., WU X. F., 2013, Dual decentralization in China's transitional economy: Welfare regionalism and policy implications for central-local relationship, in: Policy and Society, 32(1): 61-75.

20. NEWTON J., 2018, Evolutionary game theory: A renaissance, Games, 9(2), p. 1-67.

21. PENG B. H., WANG Y. Y., ELAHI E., WEI G., 2019, Behavioral game and simulation analysis of extended producer responsibility system's implementation under environmental regulations, Environmental Science and Pollution Research, 26(17): 1764417654.

22. QUE W., ZHANG Y. B., LIU S. B., YANG C. P., 2018, The spatial effect of fiscal decentralization and factor market segmentation on environmental pollution, Journal of Cleaner Production, 184: 402-413.

23. RAVETTI C., SWANSON T., JIN Y. N., MU Q., ZHANG S. Q., 2019, A dragon eating its own tail: Public control of air pollution information in China, Environment and Development Economics, 24(1): 122. 
24. SAARIMAA T., TUKIAINEN J., 2015, Common pool problems in voluntary municipal mergers, $E u$ ropean Journal of Political Economy, 38: 140-152.

25. SHEN Y. D., AHLERS A. L., 2019, Blue sky fabrication in China: Science-policy integration in air pollution regulation campaigns for mega-events, Environmental Science \& Policy, 94: 135-142.

26. SILVA E. C. D., Caplan A. J., 1997, Transboundary pollution control in federal systems, in: Journal of Environmental Economics and Management, 34: 82-101.

27. SJöBERG E., 2016 An empirical study of federal law versus local environmental enforcement, Journal of Environmental Economics and Management, 76: 14-31.

28. SJöBERG E., XU J., 2018, An empirical study of US environmental federalism: RCRA enforcement from 1998 to 2011, Ecological Economics, 147: 253263.

29. SONG M. L., DU J. T., TAN K. H., 2018, Impact of fiscal decentralization on green total factor productivity, International Journal of Production Economics, 205: 356-367.

30. XUE L., WENG L. F. YU H. Z., 2018. Addressing policy challenges in implementing Sustainable Development Goals through an adaptive governance approach: A view from transitional China, Sustainable Development, 26: 150-158.
31. YAO S., CHENG S. Y., LI J. B., ZHANG H. Y., JIA J., SUN X. W., 2019, Effect of wet flue gas desulfurization (WFGD) on fine particle (PM2.5) emission from coal-fired boilers, Journal of Environmental Sciences, 77: 32-42.

32. YOU D. M., ZHANG Y., YUAN B. L., 2019, Environmental regulation and firm eco-innovation: Evidence of moderating effects of fiscal decentralization and political competition from listed Chinese industrial companies, Journal of Cleaner Production, 207: 1072-1083.

33. ZHANG B., CHEN X. L., GUO H. X., 2018, Does central supervision enhance local environmental enforcement? Quasi-experimental evidence from China, Journal of Public Economics, 164: 70-90.

34. ZHANG M., LI H., SONG Y., LI C., 2019, Study on the heterogeneous government synergistic governance game of haze in China, Journal of Environmental Management, 248: 109318.

35. ZHAO R., HAN J. J., ZHONG S. Z., HUANG Y., 2018, Interaction between enterprises and consumers in a market of carbon-labeled products: A game theoretical analysis, Environmental Science and Pollution Research, 25(2): 1394-1404.

36. ZHAO H. Y., PERCIVAL R., 2017, Comparative environmental federalism: Subsidiarity and central regulation in the United States and China, Transnational Environmental Law, 6(3): 531-549. 